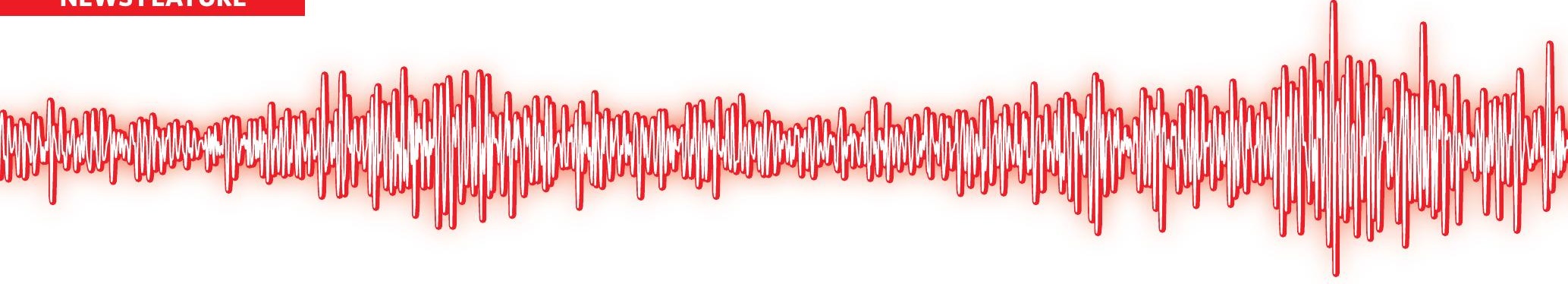

\title{
巨大断層のささやき
}

\section{The secret chatter of giant faults}

\author{
NAOMI LUBICK 2010年7月 15 日号 Vol. 466 (312-313)
}

北米大陸西部の地下で周期的に発生して長時間持続する微弱な震動は、

大地震の予測に役立つ可能性がある。

そのためにはまず、この震動の意味を明らかにする必要がある。

2010 年 7 月、ワシントン大学 (米国シ アトル）の地震学者たちは、数週間前か ら非常警戒態勢に入っていた。近くのオ リンピック半島の地下深部では、長時間 持続する微弱な震動（深部微動）が 12 〜 14 か月ごとに発生しており、次の震 動がいつ始まってもおかしくない時期 に入っていたからだ。研究者らは万全 な準備の下で、深部微動の発生を待ち 構えている。

2009 年、地震学チームは 1 年がか りでオリンピック半島の山地の地中に 100 個以上の地震計アレイを設置し、 精密な観測網を作り上げた。これらの 地震計が深部微動の兆候を検出し始め たら、研究者らは現地に駆け付け、そ の発生源の上にさらに多くの地震計を 設置し、数日ごとに地震計のバッテリー を交換したりデータをダウンロードし たりして管理を行うことになっている。 こうして、地下深部で起きている地震 活動についてできるだけ多くの情報を 手に入れようというのだ。

深部微動（あるいは非火山性微動）は、 地上では体に感じられない、数週間以内 に終息するごく小さな摇れである。しか
し、地震学者にとって、深部微動は、過 去 10 年間で最も重要な発見の 1 つであ る。深部微動を観測することで、恐ろし い被害をもたらす断層の活動について 知ることができるかもしれないからだ。 最初にこの深部微動が見つかったのは、 2002 年、日本だった。その 1 年後、北 米太平洋岸北西地区の研究チームが、シ アトルに近いカスカディアの地下で同様 の深部微動を検出した。

カスカディアでは、海岸の地下深部 に、かつてマグニチュード 9 に近い地 震を引き起こしたことがあると考えられ ている巨大な断層がある。カスカディア の深部微動が注目されているのは、この 巨大断層に沿って発生しているからであ る。研究者らは、自分たちが計画してい る精密な観測により、断層に沿った地震 活動の監視が容易になることを期待して いる。周期的に発生する深部微動を指標 に、地下の応力の変化を追跡できるかも しれないし、今後の巨大地震の発生時期 や発生場所を特定する手がかりさえ得ら れるかもしれない。

スタンフォード大学 (米国カリフォル ニア州) の地球物理学者 Greg Beroza
は、「そうした可能性を考えると、なん だかとてもワクワクしてきます」とい い、ワシントン大学の研究チームによる 観測結果を心待ちにしている。深部微動 の発生が周期的であることは、研究者が 準備を整えて観測に臨めることを意味し ている。地震活動をそんな風に詳細に観 測できる機会など、めったにない。「地 下深部の断層でなんらかの活動が起きて いて、その周期性から、そう遠くない時 期に次の活動が始まると予測できるな どと、10 年前に聞かされたら、『そんな ばかな』といっていたでしょうね」と Berozaはいう。

\section{とらえにくい信号}

地震計による深部微動の記録は、普通の 地震の記録とは異なっているようにみえ る。普通の地震は激しく始まり、高周波 エネルギーが突然生じて、急速に小さく なっていく。一方、深部微動は穏やかで、 その震動は低周波成分に富み、ひっそり と始まり、終わっていく。こうした特性 や震動の弱さのために、深部微動の発見 は難しい。プレリミナリーな観測（試し に行ったものでデータとしては不十分な 


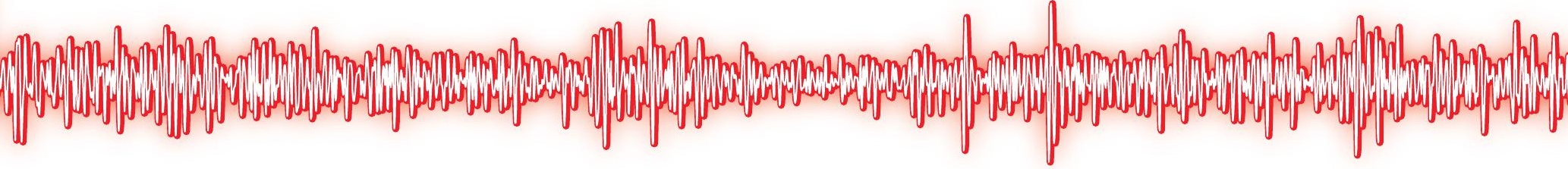

観測）から、アラスカやメキシコなどで も深部微動が見つかっている。しかし、 こうした深部微動をとらえることのでき る高感度の地震観測網をもつ地域はまだ 少なく、情報は不十分である。

深部微動を最初に発見したのは、東 京大学地震研究所の地震学者小㹉一成 だった ${ }^{1}$ 。日本には、全国の地中に設置 した地震計で常時観測を行っている高 感度地震観測網（Hi-net）がある。Hinet は、甚大な被害を出した 1995 年の 阪神淡路大震災の後に日本政府が整備 したもので、全国 600 か所の観測点か らなる。深部微動は、この Hi-net が記 録した信号の中から見つかつた。微弱な 震動はトラックの走行などの人間活動 による振動にかき消されてしまうこと があるため、高感度地震計は、こうした

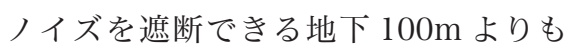
深いところに設置されている。小原が地 下 $30 \mathrm{~km}$ 以上の非常に深いところで数 週間持続する微弱な震動を発見すると、 世界中の研究者たちが、自分たちの地震 計のデータに目を凝らし、同様の記録を 探そうとした。

日本の深部微動のほとんどは、2つの プレートがぶつかり合って、一方が他方 の下に沈み込んでいく場所に沿って起き ている。北米太平洋岸北西地区の地下 にも、カナダのバンクーバー島（ブリ ティッシュコロンビア州 ) から米国カリ フォルニア州北部に伸びるカスカディア 沈み込み帯に沿って、同様の構造があ る (18 ページ図「深部微動の発生源」参 照)。ここでは、ファンデフカプレート が北米プレートの下にすべり込んでい る。1700 年に発生したと考えられてい
る最後の巨大地震以来、カスカディア沈 み込み帯の危険地域は固着（プレートど うしが強固に接着していて、エネルギー がたまっている状態）しており、研究者 らは、22 世紀中に崩壊して大災害を引 き起こすと予想している。

こうした危険があるため、研究者たち は、地下深部の沈み込み帯の状態を探る ための手段として深部微動の検出に非 常に関心をもつた。しかし、2009 年は、 観測機会を逃してしまった。ワシントン 大学の研究チームは深部微動の発生を 8 月と予想していたのだが、観測装置がほ とんど設置できていない 5 月初旬に始 まってしまったのだ。一部の震動は常 設地震計アレイを使って記録できたが、 期待したような詳細な情報は得られな かつた。

今年は、準備万全だ。常設地震計ア レイが深部微動の最初の兆候をとらえ たら、その発生源の上に観測網を設置 する。それぞれのアレイは、人間活動に よる振動が届かない場所に、25 個前後 の地震計を 200 〜 300m 間隔で配置し たものからなる。こうした研究は、米国 科学財団から非営利研究コンソーシアム Earthscope に交付された 50 万ドル（約 4200 万円）の助成金に支えられている。

ワシントン大学の地震学者で、この プロジェクトの主任研究者の 1 人であ るJohn Vidale は、「我々が現在行って いる実験は、これまで見ることができな かったものを見せてくれる点で、前例の ないものになるでしょう」という。

Vidale によると、研究チームが「ア レイのアレイ」とよんでいるこの観測網 は、地震波がそれぞれの地震計に到達す
る時刻を比較することで、深部微動の発 生源を正確に特定できるという。「我々 が耳で音を聞いて、どの方向から聞こえ てくるのかを当てられるのと同じことで す」と彼はいう。

深部微動の発生源を巡っては激しい論 争が起きている。日本では、深部微動は 2つのプレートの境界面（沈み込み帯一 断層境界) で発生していることが観察さ れており、ここでは巨大地震も発生して いる。一方、太平洋地球科学センター(カ ナダ・ブリティッシュコロンビア州シド ニー）の Honn Kao らによると、カス カディアでは、地震計の記録からは一部 の微動が断層面上で発生している可能性 が示唆されるという²。

\section{深部微動の発生源}

深部微動の発生源の位置を特定すること は、深部微動を発生させる物理的過程の 解明に役立つはずだ。深部微動は地下 数十 $\mathrm{km}$ の深さで発生する。ここは、低 温の地殼が、高温のマントルに引き込ま れる所である。上部地殼の岩石はもろく、 応力を受けて破壊され、地震を引き起こ す。しかし、マントル中の岩石は非常に 高温なので、圧力を受けても破壊されず にひずんでいく。深部微動は、沈み込む プレートの温度が上昇し、岩石が柔軟に なってきた程度の、複雑な領域で起こる ようにみえる。

Nature 2010 年 7 月 15 日号に発表さ れた研究 ${ }^{3}$ は、日本で観測されている一 部の深部微動については、その発生過程 を解明する役に立つかもしれない。論文 著者で、東京大学の地震学者の并出哲は、 四国で観察される深部微動が、その場所 
の沈み込み帯にある岩石の種類に影響を 受けている可能性があると指摘した。井 出は、一部の深部微動の発生源が縞状に 並んでいて、その方向が、沈み込んでい くプレートの過去 1000 万年間の移動方 向と一致していることを発見した。彼は、 これらの縞から、日本列島の下に潜り込 んでいく海洋プレート上の海山 (かつて の火山が沈下したもの) が通つた経路を たどれるとする仮説を提案した。

この仮説が正しいなら、海山が深部微 動に作用する過程は 2 つ考えられると 井出はいう。1 つは、海山等が沈み込む 途中でマントルに付けた凹凹が不規則に すべるというものである。もう 1 つは、 沈み込むプレートの脱水反応で生成され た水によってマントルの岩石が変成し、 境界面の性質が変化して、安定したすべ りからぎくしゃくした運動になり、微弱 な振動が生み出されるというものだ。
Berozaは、井出の研究結果はプレリ ミナリーなものにすぎないというが、ど うやって断層に沿った岩石の特性が数 百万年も保存されて、今日の深部微動に 影響を及ぼしているのかを示唆する「非 常に重要な結果」であると評価している。 日本の深部微動と同様、カスカディアの 深部微動も帯状に発生することがあり、 沈み込んでいく岩石の何らかの特性を反 映している可能性がある。

研究者たちは、岩石に圧力をかけた ときの摩擦や間变率などの特性の変化 を検証した新旧の室内実験のデータを 用いて、普通の地震ではなく深部微動が 発生する条件を明らかにしようとしてい る。スタンフォード大学の地球物理学者 Paul Segall は、これらの研究は、沈み 込み帯の深さでの断層の動きを明らかに するのに役立つかもしれないという。



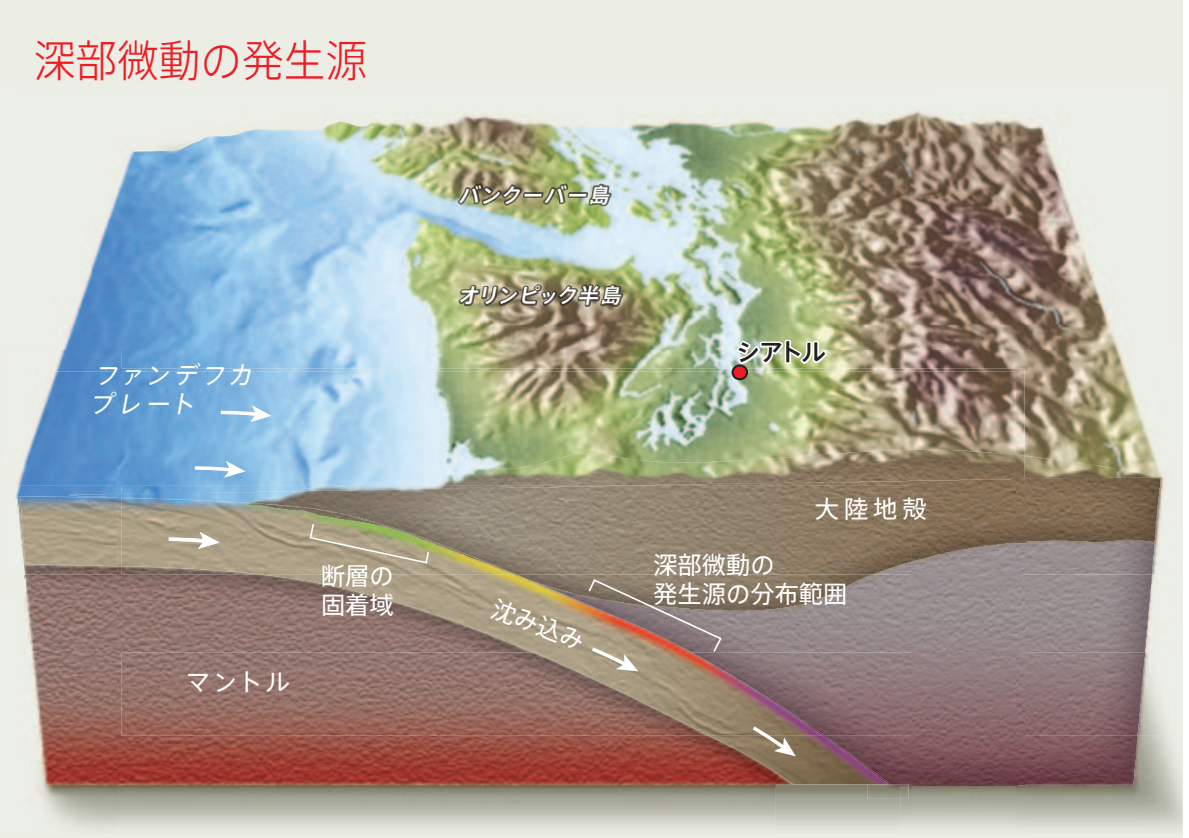

カスカディア沈み込み帯に沿って、海洋地款 の一部が北米プレートの下にすべり込んでい る。プレートの間の断層面上部は固着して圧 力をため込んでおり、将来、これが一気に解 放されて大地震を引き起こすと予想されてい る。断層の下部や周辺領域では、ほぼ毎年、深 部微動が発生している。周期的に発生する深 部微動を調べることは、地震学者が沈み込み 帯の状態を監視する役に立つかもしれない。

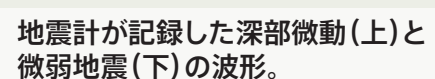
微弱地震(下)の波形。

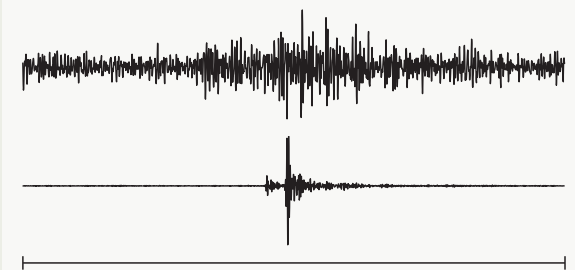

100 秒

\section{大地震との関係}

研究者らは、深部微動と、同じ断層で発 生する大地震との関連についても知りた がっている。よく観測されている日本と カスカディアの深部微動は、沈み込んで いくプレート上の大地震の発生場所付近 で生じる傾向がある。深部微動は、大地 震を引き起こすエネルギーを蓄えている 「固着」領域の下方で発生しているのだ ( 左下図「深部微動の発生源」参照)。

ワシントン大学の地球物理学者 Joan Gombergによると、研究者たちは今、 断層における圧力の変化に連動するよ うな深部微動のパターンの変化を探し ているという。そのような関係がわか れば、大地震の前兆を見つけるために、 深部微動の監視を始めることができる。 これまでに、興味深い手がかりがいくつ か見つかっているが、確実なものはまだ ない。例えば、カリフォルニア州のサン アンドレアス断層では、マグニチュード 1 または 2 の地震とともに深部微動が発 生したが、両者の直接的な関係はまだ証 明されていないのだ 4

一方、小原らは、日本の地下で発生 する深部微動について、より詳細なデー 夕を集めるために、さらなる監視シス テムの設置を計画している。カスカディ アの研究者たちも、2010 年の深部微動 を逃すまいと周到な準備をしている。

ワシントン大学の地震学者Ken Creager は、深部微動をとらえ損なっ た 2009 年の失望を思い出して、「深部 微動は、時計仕掛けのように周期的に発 生しますが、その周期はあまり厳密では ないのです」という。けれども今年は自 信がある。「今回こそは、逃しません」。 【訳注：2010 年 8 月 8 日、彼らはつい にカスカディアの深部微動をとらえた。】

（翻訳：三枝小夜子）

Naomi Lubick はチューリヒ ( スイス ) に拠点を置く フリーランスのライター。

1. Obara, K. Science 296, 1679.1681 (2002).

2. Kao, H. et al J. Geophys. Res. 114, B00A12 (2009).

3. Ide, S. Nature 466, 356-359 (2010).

4. Nadeau, R. M. \& Guilhem, A. Science 325, 191-193 (2009). 